\title{
Morphological variability of Trifolium repens L. (Fabaceae)
}

\author{
Kimete Lluga-Rizani ${ }^{1, *}$ (D) , Dubravka Šoljan ${ }^{2}$ (1) , Naim Berisha ${ }^{1}$ (D), \\ Kemajl Kurteshi ${ }^{1}$, ${ }^{\text {, Kasum Letaj }}{ }^{1}$ (1)
}

Key words: Trifolium repens, morphological variability, locations, taxonomic revision, Kosovo.

Ključne besede: Trifolium repens, morfološka variabilnost, lokacije, taksonomska revzija, Kosovo.

\begin{abstract}
The subject of our research was Trifolium repens $\mathrm{L}$. The aim was to assess the level of morphological and anatomical variability among populations from different habitats (meadows, roadsides, subalpine slopes) and different altitudes (891-1881 m) in Brezovica (Sharri Mountain, Kosovo). The investigation covered 26 morphological and anatomical traits in populations from 12 locations. From the results obtained during this research, it can be concluded that there is a significant difference among populations for most micro- and macro-morphological traits. There is also a tendency towards a reduction of most of the average values of the investigated parameters (total plant height, total leaf length, leaf petiole length, peduncle length, fruit weight, number of flowers in an inflorescence, stomata length on the upper leaf surface, and diameter of collateral bundle) in relation to altitude increase. However, trichome length showed consistency and was not affected by habitat and altitude changes. The results also lead to a proposal for taxonomic revision of this taxon.
\end{abstract}

\section{Izvleček}

Objekt naše raziskave je bila vrsta Trifolium repens L., cilj pa ugotoviti morfološko in anatomsko variabilnost med populacijami na različnih rastiščih (travnik, rob ceste, subalpinska pobočja) in nadmorskih višinah (891-1881 m) na Brezovici (Šara, Kosovo). Raziskava je obsegala 26 morfoloških in anatomskih znakov v populacijah iz 12 lokacij. Iz rezultatov lahko zaključimo, da obstajajo značilne razlike med populacijami v mikro in makro morfoloških znakih. Večina povprečnih vrednosti preučevanih znakov (višina rastlin, dolžina listov, dolžina listnih pecljev, dolžina cvetnih pecljev, število cvetov v socvetju, dolžina rež na zgornji listni površini in premer žil) se z nadmorsko višino zmanjšuje. Vendar pa je dolžina laskov konstantna in nanjo ne vpliva tip rastišča ali spremembe v nadmorski višini. Rezultati omogočajo predloge za taksonomsko revizijo tega taksona.

Received: 22. 1. 2019

Revision received: 9. 11. 2020

Accepted: 14.5 .2021

\footnotetext{
1 Department of Biology, Faculty of Mathematical Natural Sciences, University of Prishtina, George Bush Street No number, Prishtina, Kosovo. E-mail: naim.berisha@uni-pr.edu; kemajlkurteshi@yahoo.com; kletaj2003@yahoo.com

2 Department of Biology, Faculty of Mathematical Natural Sciences, University of Sarajevo, Zmaja od Bosne 33-35, Sarajevo 71000, Bosnia and Hercegovina. E-mail: dr.dsoljan@gmail.com

* Corresponding author. Email: kimete.lluga@uni-pr.edu
} 


\section{Introduction}

Trifolium repens $\mathrm{L}$. or white clover belongs to Leguminosae (= Fabaceae), the third largest family of flowering plants (727 genera) (Lewis 2005). The Trifolium genus is one of the largest genera in the family, with ca. 255 species. The Trifolium genus is thought to have originated in the Mediterranean in the early Miocene period, 16-23 million years ago (Ellison et al. 2006). White clover has tended to naturalize in temperate regions of the world with more than $750 \mathrm{~mm}$ annual rainfall (Jahufer et al. 2002). White clover is distributed in temperate and subtropical climates in both northern and southern hemispheres (Ellison et. al. 2006) and is also distributed widely in Kosovo. It has extremely broad edaphic tolerance, growing on soils ranging from markedly acid to highly calcareous (Snaydon 1962). Its symbiotic relationship with nitrogen fixing bacteria contributes to its wide edaphic tolerance. Due to the prostrate growth of stolons, once established, this creeping habit and the attendant characteristics of rooting at the nodes make $T$. repens extremely successful in colonizing bare ground and in invading pastures and lawns (Turkington \& Burdon 1983). White clover is a highly variable species, commonly showing considerable inter- and intraspecific differences in a wide range of morphological characters (Turkington \& Burdon 1983). The taxonomic status of the various forms of white clover is further complicated by the existence and widespread agricultural use of a considerable number of commercial cultivars. White clover is phenotypically diverse and cultivars suited to many grazing and management systems are available (Abberton et al. 2006).

It is the most important pasture legume in many temperate parts of the world (Archer \& Robinson 1989). The agronomic strength of white clover is its phenotypic plasticity, underpinned by its high genetic diversity arising from being an obligate out-crosser (Williams 1987).

Evaluation of the altitude effect, habitat change and influence of all environmental factors on plants can be successfully demonstrated on some plant taxa that have a broad distribution, such as the Trifolium genus. Each species on planet Earth has its own specificity and is a reflection of lengthy evolutionary processes in a given dimension of time and space. Together with the modern molecular biological approach to species evaluation, classical methods are still regarded as fundamental and irreplaceable. In particular, the morphological evaluation of individual plant species can provide a number of relevant answers to many current and open questions.

This is especially relevant with representatives of the vascular flora plants, important to man from both scientific and practical points of view. Establishment of more functional biodiversity databases entails a variety of research using a large number of disciplines: morphology, taxonomy, chorology, biogeography, ecology, phylogeny, bioinformatics, which enables a more suitable positioning of each biodiversity unit in the scientific system, and opens possibilities of their application as biological resources. Given what was said above, the baseline for the research was the hypothesis that morphological variability is one of the key responses of any individual and population to the qualitative-quantitative characteristics of the environment in which they grow, one of the best indicators of evolutionary and phylogenetic interactivity and the mutual interaction of genotype and environment. There is a significant correlation between genotype and phenotype across different ecotypes as an adaptive response to specific environmental conditions. Given its broad geographical distribution, Trifolium repens might show variability in relation to dominant ecological factors and serve as a paradigm for unique patterns of ecologicalmorphological differentiation in the natural ecosystem.

The aim of this research was therefore to determine the forms and levels of individual, population and interpopulation variability of Trifolium repens depending on the ecological factors under which they develop, and to identify the most variable and consistent morphological characters that can serve to provide a more complete and critical taxonomic analysis and revision of this variable taxon.

\section{Methods}

\section{Study area}

Plant individuals of Trifolium repens $\mathrm{L}$. were collected in a vertical profile of Brezovica - Sharri Mountain (Kosovo, Western Balkans). Due to the morphological development of the Kosovo highlands, local climatic microclimatic specifics are present on Sharri Mountain (Pllana 2015).

\section{Research methodology}

\section{Fieldwork}

Plant individuals of Trifolium repens $\mathrm{L}$. were collected in flowering and fruiting stages from 12 topo-geographically-ecologically diverse locations on a vertical profile of Brezovica from 891 to $1881 \mathrm{~m}$ altitude. Thirty plant individuals were collected from each location, whereby 10 of them were preserved in $70 \%$ alcohol, and 20 plant individuals were placed and dried in newspaper. The locations were identified by numbers (1 to 12 ) (Table 1 ). 
Table 1: Geographic areas studied and ecological features.

Tabela 1: Proučevana območja in ekološke značilnosti.

\begin{tabular}{|c|c|c|c|c|c|c|}
\hline Habitat & 1 & 2 & 3 & 4 & 5 & 6 \\
\hline Sample number & 30 & 30 & 30 & 30 & 30 & 30 \\
\hline Altitude (m) & 891 & 922 & 1002 & 1020 & 1044 & 1187 \\
\hline $\begin{array}{l}\text { Geographical } \\
\text { Coordinates }\end{array}$ & $\begin{array}{c}42^{\circ} 13^{\prime} 18.63^{\prime \prime} \mathrm{N} \\
21^{\circ} 0^{\prime} 33.66^{\prime \prime} \mathrm{E}\end{array}$ & $\begin{array}{l}42^{\circ} 13^{\prime} 5.99^{\prime \prime} \mathrm{N} \\
21^{\circ} 0^{\prime} 32.61^{\prime \prime} \mathrm{E}\end{array}$ & $\begin{array}{c}42^{\circ} 12^{\prime} 22.23^{\prime \prime} \mathrm{N} \\
21^{\circ} 0^{\prime} 43.26^{\prime \prime} \mathrm{E}\end{array}$ & $\begin{array}{c}42^{\circ} 12^{\prime} 27.44^{\prime \prime} \mathrm{N} \\
21^{\circ} 0^{\prime} 25.30^{\prime \prime} \mathrm{E}\end{array}$ & $\begin{array}{c}42^{\circ} 12^{\prime} 16.47^{\prime \prime} \mathrm{N} \\
21^{\circ} 0^{\prime} 26.37^{\prime \prime} \mathrm{E}\end{array}$ & $\begin{array}{c}42^{\circ} 11^{\prime} 32.88^{\prime \prime} \mathrm{N} \\
21^{\circ} 0^{\prime} 44.48^{\prime \prime} \mathrm{E}\end{array}$ \\
\hline Habitat & Rich meadow & $\begin{array}{l}\text { Rich meadow close } \\
\text { to the river }\end{array}$ & $\begin{array}{l}\text { humid meadow } \\
\text { close to the river }\end{array}$ & $\begin{array}{l}\text { Along the road, } \\
\text { stony and sandy }\end{array}$ & $\begin{array}{l}\text { Along the road, } \\
\text { stony and sandy }\end{array}$ & $\begin{array}{c}\text { Meadow close to } \\
\text { the road }\end{array}$ \\
\hline Plant community & $\begin{array}{l}\text { Festuco rupicolae- } \\
\text { Lolietum perennis }\end{array}$ & $\begin{array}{l}\text { Alopecurion } \\
\text { pratensis + } \\
\text { Cynosurion }\end{array}$ & $\begin{array}{l}\text { Caro-Poëtum } \\
\text { pratensis }\end{array}$ & $\begin{array}{l}\text { Convolvulo- } \\
\text { Agropyron }\end{array}$ & $\begin{array}{l}\text { Caro-Poëtum } \\
\text { pratensis }\end{array}$ & $\begin{array}{l}\text { Caro-Poëtum } \\
\text { pratensis }\end{array}$ \\
\hline Habitat & 7 & 8 & 9 & 10 & 11 & 12 \\
\hline Sample number & 30 & 30 & 30 & 30 & 30 & 30 \\
\hline Altitude (m) & 1416 & 1420 & 1608 & 1747 & 1790 & 1885 \\
\hline $\begin{array}{l}\text { Geographical } \\
\text { Coordinates }\end{array}$ & $\begin{array}{l}42^{\circ} 11^{\prime} 6.88^{\prime \prime} \mathrm{N} \\
21^{\circ} 0^{\prime} 22.52^{\prime \prime} \mathrm{E}\end{array}$ & $\begin{array}{c}42^{\circ} 11^{\prime} 19.76^{\prime \prime} \mathrm{N} \\
21^{\circ} 0^{\prime} 29.84^{\prime \prime} \mathrm{E}\end{array}$ & $\begin{array}{c}42^{\circ} 10^{\prime} 53.99^{\prime \prime} \mathrm{N} \\
21^{\circ} 1^{\prime} 35.38^{\prime \prime} \mathrm{E}\end{array}$ & $\begin{array}{c}42^{\circ} 10^{\prime} 55.82^{\prime \prime} \mathrm{N} \\
21^{\circ} 2^{\prime} 8.46^{\prime \prime} \mathrm{E}\end{array}$ & $\begin{array}{c}42^{\circ} 10^{\prime} 59.12^{\prime \prime} \mathrm{N} \\
21^{\circ} 2^{\prime} 21.68^{\prime \prime} \mathrm{E}\end{array}$ & $\begin{array}{l}42^{\circ} 11^{\prime} 4.27^{\prime \prime} \mathrm{N} \\
21^{\circ} 2^{\prime} 36.42^{\prime \prime} \mathrm{E}\end{array}$ \\
\hline Habitat & Along the road & $\begin{array}{c}\text { Under the tree } \\
\text { shadow, close to } \\
\text { the road }\end{array}$ & $\begin{array}{l}\text { Along the road, } \\
\text { stony and sandy, } \\
\text { poor vegetation } \\
\text { coverage }\end{array}$ & $\begin{array}{l}\text { Green humid area } \\
\text { under the shadow } \\
\text { of a Hotel building, } \\
\text { subalpine band }\end{array}$ & $\begin{array}{l}\text { Pedestrian path } \\
\text { leading uphill to the } \\
\text { top of a mountain, } \\
\text { in the subalpine } \\
\text { zone. The soil is very } \\
\text { dry and exposed to } \\
\text { the sun. }\end{array}$ & $\begin{array}{l}\text { Pedestrian path } \\
\text { leading uphill } \\
\text { to the top of a } \\
\text { mountain, in the } \\
\text { subalpine zone. The } \\
\text { soil is very dry and } \\
\text { exposed to the sun. }\end{array}$ \\
\hline Plant community & $\begin{array}{l}\text { Festuco rupicolae- } \\
\text { Lolietum perennis }\end{array}$ & $\begin{array}{l}\text { Festuco rupicolae- } \\
\text { Lolietum perennis }\end{array}$ & Juncetum tenuis & $\begin{array}{c}\text { Chaerophyllo } \\
\text { hirsuti-Rumicetum } \\
\text { alpini }\end{array}$ & $\begin{array}{l}\text { Chaerophyllo hirsuti- } \\
\text { Rumicetum alpini }\end{array}$ & $\begin{array}{l}\text { Chaerophyllo hirsuti- } \\
\text { Rumicetum alpini }\end{array}$ \\
\hline
\end{tabular}

\section{Laboratory work}

The plant individuals placed in alcohol were used to make permanent specimens. For the purpose of counting and measuring the stoma and trichoma on the leaf epidermis, specimens were prepared using the nail varnish methodology (Zhenzhu \& Guangsheng 2008). A manual microtome was used for preparation of leaf cross section specimens. Dried plant material was used for morphometric analysis.

\section{Analysis of micro- and macro-morphological traits}

A comparative-morphometric method was used to evaluate the morphological variability of individuals and populations. A SWIFT M10L SERIES microscope was used for examination of the variability of the stomatal apparatus, trichome length, midrib vascular bundle, palisade and sponge cell length. The following traits were analyzed: total plant height, total leaf length, length and width of the first and the middle leaflet, length of the leaf petiole, corolla length, calyx length, length of the calyx tube, number of flowers in an inflorescence, length of the inflorescence peduncle, length of the short and long calyx teeth, fruit length, width and weight, number of stomata per $\mathrm{mm}^{2}$ on the upper and lower leaf epidermis, length and width of stomata on the upper and lower leaf epidermis, length of trichomes on the lower leaf epidermis, diameter of the midrib vascular bundle, and the length of palisade and spongy tissue layers.

\section{Statistical analysis}

Assessment and interpretation of the level of variability of specific traits, the degree of correlation, as well as analysis of the significance of the obtained results, were done in accordance with valid statistical-biological and ecological samples contained in a software package (SIGMA 2010) and Excel program. To obtain an idea of the variability of the examined morphological-anatomical traits, average value $(\mathrm{AV})$, standard deviation (STD), correlation (Spearman rank correlation) minimum (MIN), first and third quartile (Q1 and Q3), median (MED) and maximum (MAX) values were calculated, and variance analysis using the Tukey test and Holm-Sidak method was applied. 


\section{Results}

The results of the investigation of micro- and macro-morphological traits of the leaf, flower and fruit, as well as plant height, will be presented in this part.

The results show a progressive reduction of plant height $(28.8 \mathrm{~cm}$ - population $3 ; 5.28 \mathrm{~cm}$ - population 12$)$ and a significant difference among populations that inhabit different locations. (Figure 1). The biggest difference was found between populations from lowland locations ( 3 , $4,5,6$ and 8), where the temperature and humidity are more favorable, and location 12 , which is located at the highest altitude.

\section{A. Leaf Morphology and Anatomy}

The leaf of T. repens is a compound leaf of three leaflets with a relatively long petiole $(23.1 \mathrm{~cm})$, covered with a single layer of cells, the so-called epidermis. The cells of the upper leaf epidermis are mostly hexagonal, with straight anticlinal walls (Figure S1). Cells of the lower leaf epidermis are bigger in size and with curved walls that make possible a very strong connection between cells (Figure S2). On the lower leaf epidermis of Trifolium repens there are simple, multicellular trichomes $(87.290 \mu \mathrm{m}$ long) with a living content (Figure S2).

The measurements of leaf petiole length, length and width of the first and middle leaflet and total leaf length show significant differences among populations

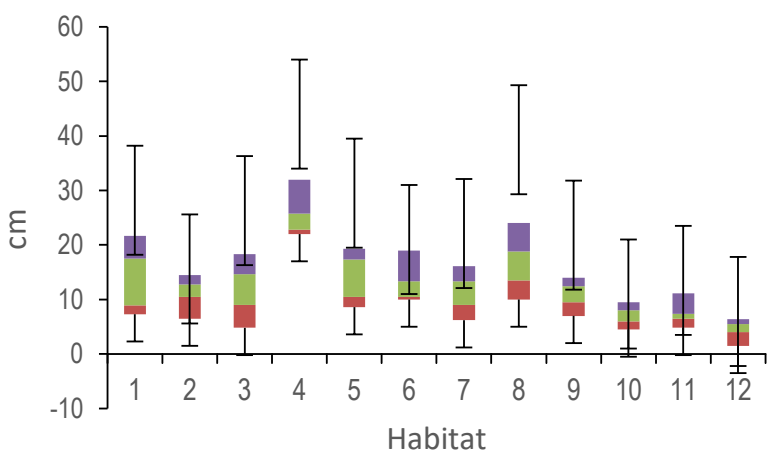

Figure 1: The box- plot diagram of Trifolium repens height from 12 localities.

Slika 1: Škatla z brki višine osebkov vrste Trifolium repens na 12 lokalitetetah.

(Figure 2.1, 2.2, 2.4). The biggest significance was established between the population of location 2 and populations from all other locations. Even though population 10 was located at a very high altitude, due to the microclimate it showed a similar response to the environmental conditions of lowland populations, significance was therefore established between location 10 and locations 9, 11 and 12. The most consistent and resistant trait in relation to habitat and altitude changes was trichome length, because there was no significant difference established among the various populations (Figure 2.3). Variance analyses were conducted using the Holm-Sidak and Tukey tests.
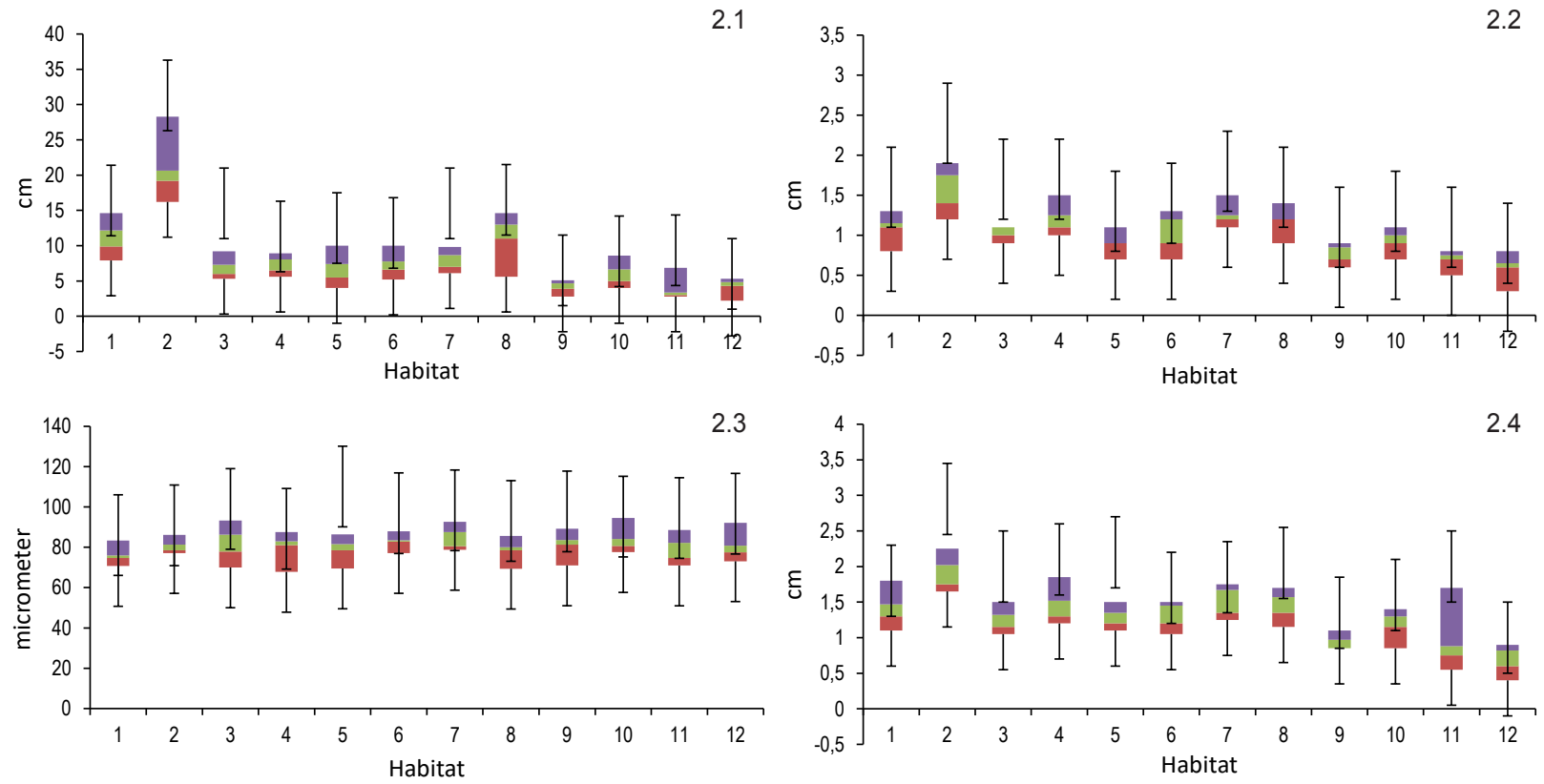

Figure 2: The box-plot diagram of Trifolium repens leaf traits from 12 localities: 2.1 The leaf petiole length, 2.2 Maximal width of the middle leaflet, 2.3 Trichoma length on the lower leaf epidermis, 2.4 The total leaf length.

Slika 2: Škatla z brki listnih značilnosti Trifolium repens na 12 lokalitetetah: 2.1 listni pecelj, 2.2 maksimalna širina srednjega lističa, 2.3 dolžina laskov na spodnji strani lista, 2.4 celotna dolžina lista. 
Almost all macromorphological traits, i.e., total plant height, leaf petiole length, total leaf length, width of the first and middle leaflet and other traits, showed a decreasing trend of average values with increasing altitude (Figure 3).

Leaves are amphystomatic (Figure S1 and Figure S2). The obtained results showed that the number of stomata per $\mathrm{mm}^{2}$ is regularly higher on the upper leaf epidermis (218) than on the lower leaf epidermis (99) (Figure 4.1, 4.2). The investigation of stomata width and length on the upper leaf epidermis indicated that average values were lower $(9.0 \mu \mathrm{m} ; 15.9 \mu \mathrm{m})$ than the width and length of stomata on the lower leaf epidermis $(16.4 \mu \mathrm{m} ; 25.1 \mu \mathrm{m})$ (Figure 4.3-4.6). A significant difference between the population from location 12 and populations from all other locations was established for all stomata traits.
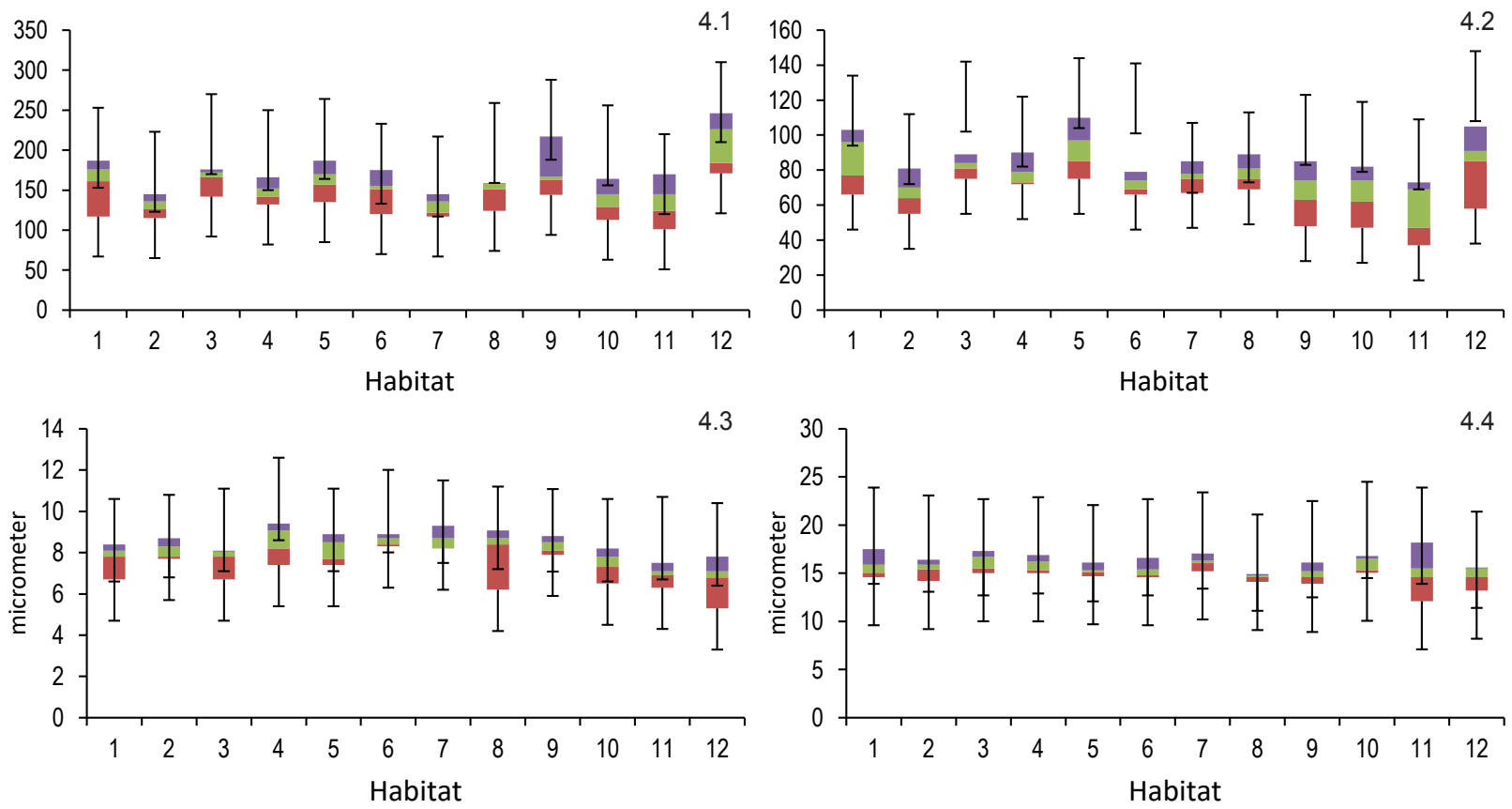

The middle leaflet width

Figure 3: The negative correlation of some Trifolium repens morphological parameters and altitude.

Slika 3: Korelacija morfoloških značilnosti Trifolium repens z nadmorsko višino.

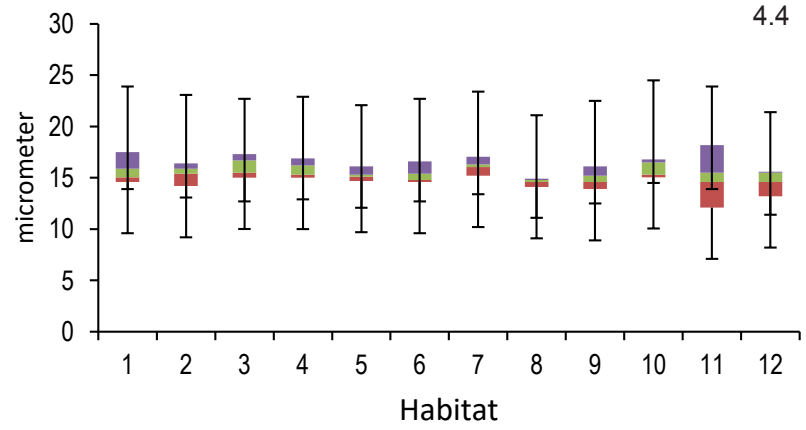

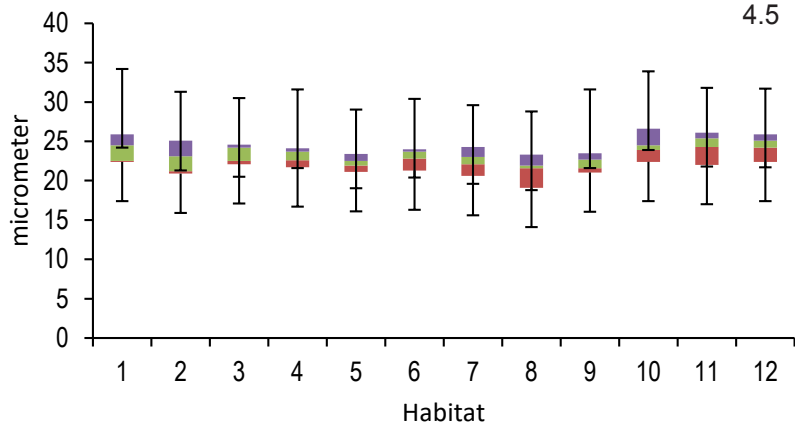

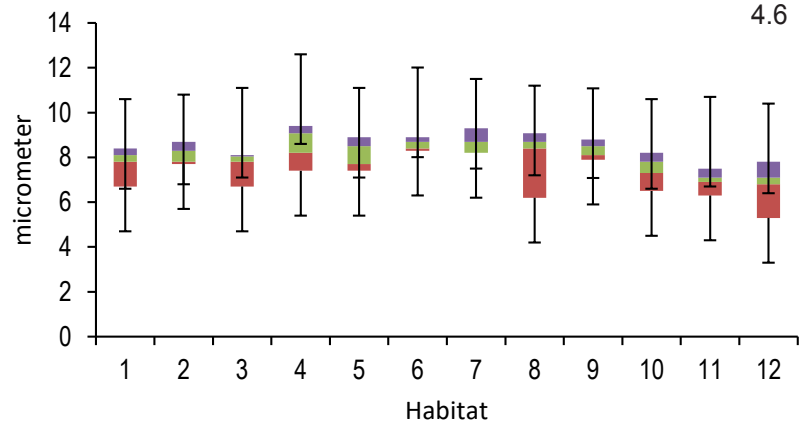

Figure 4: The box-plot diagrams of Trifolium repens stomata traits from 12 localities: 4.1 Number of stomata per mm² on the upper leaf epidermis, 4.2 Number of stomata per $\mathrm{mm}^{2}$ on the lower leaf epidermis, 4.3 Stomata width on the upper leaf epidermis, 4.4 Stomata width on the lower leaf epidermis, 4.5 Stomata length on the lower leaf epidermis, 4.6 Stomata width on the upper leaf epidermis.

Slika 4: Škatla z brki listnih značilnosti Trifolium repens na 12 lokalitetetah: 4.1 število rež na $\mathrm{mm}^{2}$ na zgornji strani lista, 4.2 število rež na mm² na spodnji strani listac, 4.3 širina rež na zgornji strani, 4.4 širina rež na spodnji strani, 4.5 dolžina rež na spodnji strani, 4.6 dolžina rež na zgornji strani. 
The Trifolium repens leaf contains mesophyll differentiation in palisade and spongy tissue between the adaxial and abaxial epidermis. The leaf mesophyll investigation results show that palisade tissue is made of 2-3 layers of cylindrical cells, whereas spongy tissue is made of 3-5 layers of rounded, elyptical or cylindrical cells, extended horizontally and with large intercellulars (Figure S3). The average values of palisade tissue layer length varied from 45.4 to $74.6 \mu \mathrm{m}$, that of the spongy layer from 33.6 to $47.6 \mu \mathrm{m}$ and of the vascular bundle from 76.3 to $219.6 \mu \mathrm{m}$ (Figure 5.1, 5.2, 5.3). The results showed a significant difference between populations from habitats that have different exposures to the light factor, because light stimulates the formation of palisade tissue. The biggest significant difference for palisade tissue length was
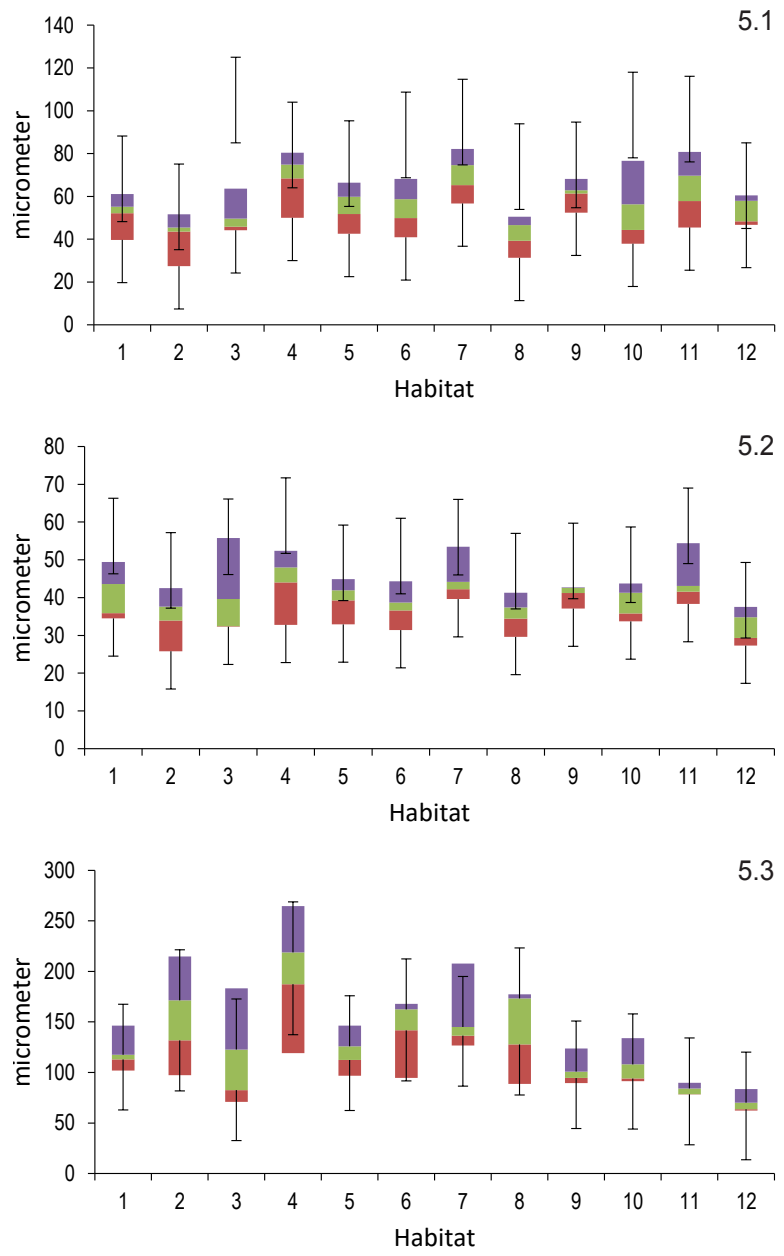

Figure 5: The box-plot diagrams of Trifolium repens leaf mesophyll traits from 12 localities: 5.1 The length of palisade tissue layer, 5.2 The length of the spongy tissue layer, 5.3 The diameter of vascular bundle. Figure 5: Škatla z brki značilnosti listenga mezofila vrste Trifolium repens na 12 lokalitetetah: 5.1 dolžina palisadnega tkiva, 5.2 dolžina gobastega tkiva, 5.3 premer žile. found between populations from location 2 and those from locations 8, 9 and 11, then between locations 4 and 8 versus 2 and 8 .

The leaf vascular bundles are collateral (with a diameter of $219.620 \mu \mathrm{m}$ ). The mechanical tissue forms capes around the two poles of the vascular bundle (Figure S4). The investigation of midrib vascular bundle diameter indicated that there is a significant difference between populations from locations $9,10,11$ and 12 and populations from lowland locations $(1,2,3,4,5)$.

The correlation between the number of stomata on the upper leaf epidermis (172.6 - population 1 and 218.2 population 12), the stomata length on the lower leaf epidermis and increasing altitude was positive. A negative correlation between stomata length on the upper leaf epidermis, vascular bundle diameter and increasing altitude was found. No clear correlation was found between stomata width on the upper and lower leaf epidermis, leaf epidermis trichomes length, palisade and spongy layer length and increasing altitude (Figure 6).

\section{B. Flower Morphology}

Flowers of Trifolium repens have white, yellowish or pinkish corolla. The corolla is $7 \mathrm{~mm}$ long. The corollas form heads or capitulum inflorescences (55.9 flowers per inflorescence). An investigation of peduncle, corolla, calyx, calyx tube and calyx teeth length, and the number of flowers in an inflorescence was conducted (Figure 7.1-7.4), The flower calyx ( $5.2 \mathrm{~mm}$ long) is formed of a calyx tube ( $3 \mathrm{~mm}$ long) and calyx teeth. There are usually five calyx teeth, with two out of five being longer $(2.2 \mathrm{~mm}$ long) (Figure S5). Variance analyses showed that the long calyx teeth are more sensitive and show significant differences even among populations from highland locations with very similar environmental conditions and floristic composition, such as locations 12 and 11 versus location 9. The short calyx teeth show a bigger signifcant difference between lowland and highland habitats.

Investigation of the number of flowers in an inflorescence, total calyx length, calyx tube length, and short and long calyx teeth length, showed the lowest average values for populations from location 12. Average values of total calyx length mainly showed a high significant difference between populations from locations with bigger differences in altitude. The biggest significant difference for total corolla length was found between populations from locations 3 and 7. Average values of the number of flowers in an inflorescence were very variable among different populations but the biggest difference was noticed between population 5 and most of the other populations. 


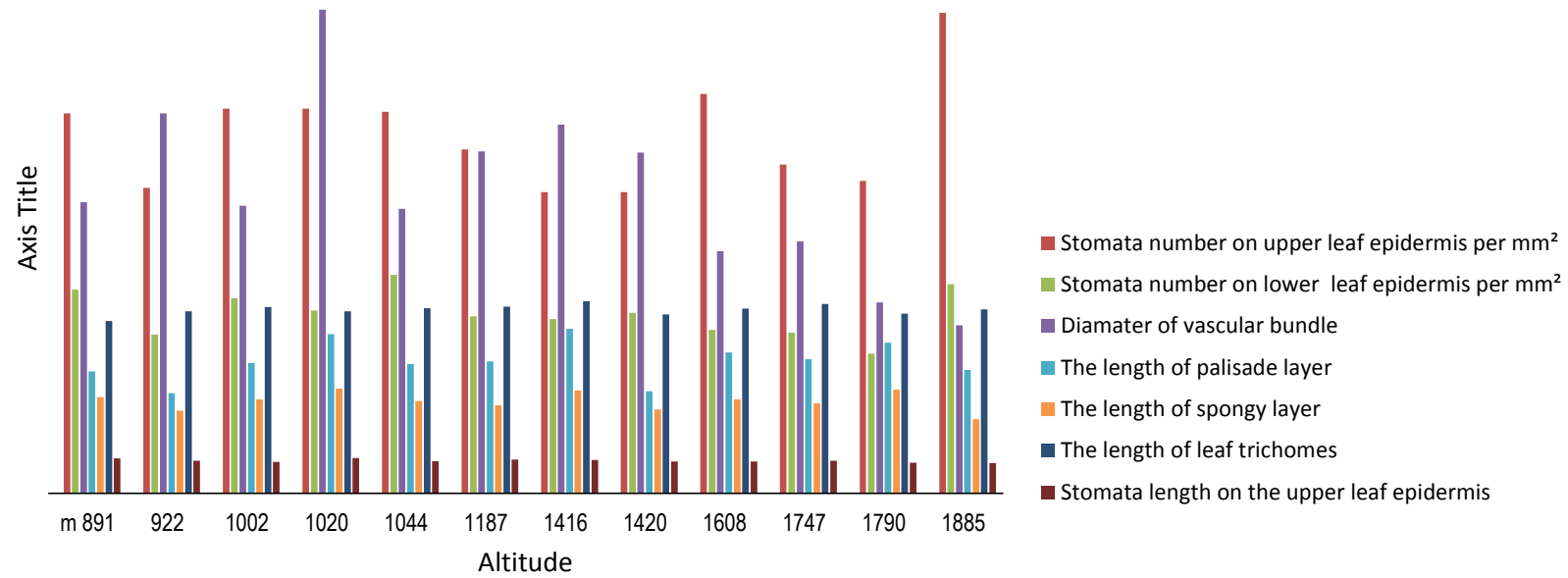

Figure 6: The correlation of some Trifolium repens micro-morphological parameters with altitude.

Figure 6: Korelacija mikromorfoloških značilnosti Trifolium repens z nadmorsko višino.
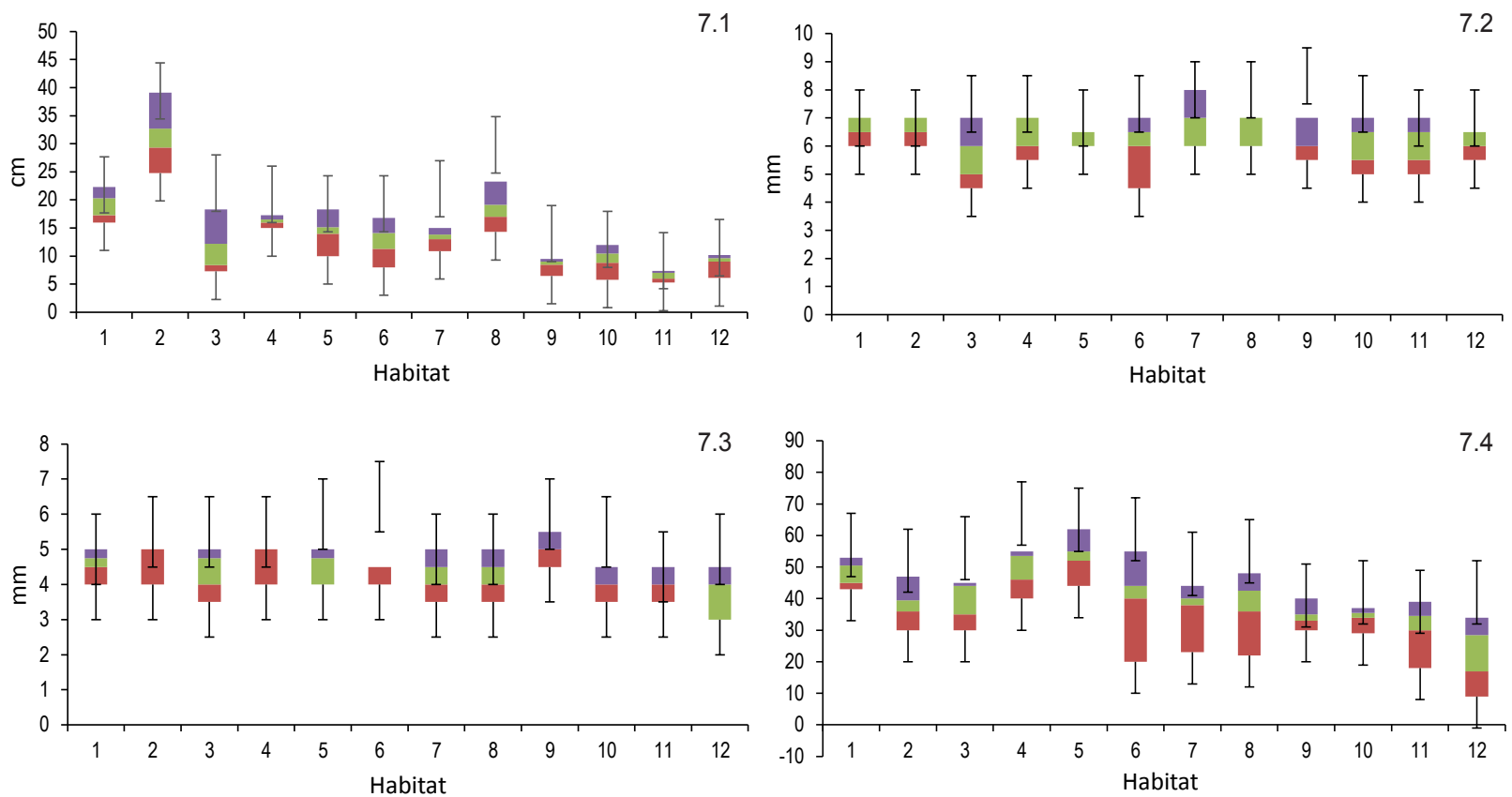

Figure 7: The box-plot diagrams of Trifolium repens flower traits from 12 localities: 7.1 The peduncle length, 7.2 The total corolla length, 7.3 The total calyx length, 7.4 Number of flowers in inflorescence.

Figure 7: Škatla z brki značilnosti cvetov vrste Trifolium repens na 12 lokalitetetah: 7.1 dolžina peclja socvetja, 7.2 dolžina venca, 7.3 dolžina čaše, 7.4 število cvetov v socvetju.

\section{Fruit Morphology}

The fruit of Trifolium repens is a legume with 3-4 seeds (Figure S6). Seeds are golden to brownish (Figure S7). They are ovoid at the bottom but wider, more or less heart shaped at the top. An investigation of fruit length (5.5 mm long) and width (1.5 mm wide) was conducted (Figure 15.1, 15.2). Differences among populations for fruit width and length were significant. The highest value of fruit length and width was seen in individuals from location 2, and the lowest in those from location 11. A significant difference in fruit length was found between population 2 and the other populations.

Correlation analysis was performed for the all investigated micro- and macro-morphological parameters (See Table S1). 

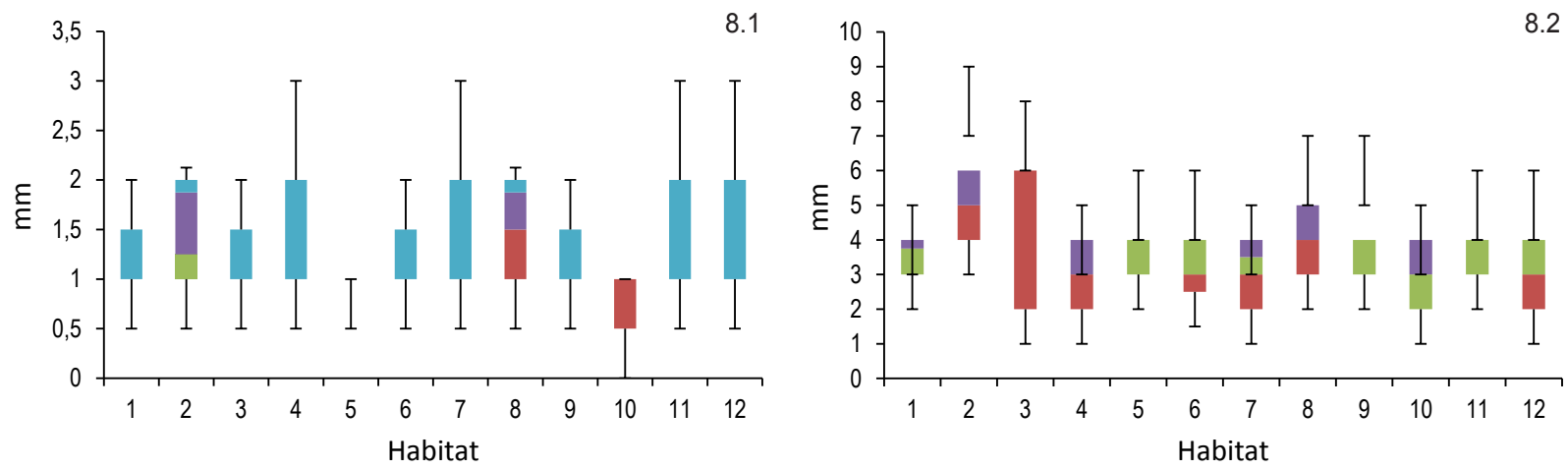

Figure 8: The box-plot diagrams of Trifolium repens fruit traits from 12 localities: 8.1 - The fruit maximal width, 8.2 - The fruit length.

Slika 8: Škatla z brki značilnosti plodov vrste Trifolium repens na 12 lokalitetetah: 8.1 maksimalna širina plodu, 8.2 dolžina plodu.

\section{Discussion}

Trifolium repens L. in our study area, Brezovica (Sharri Mountain), thrives in habitats beside roads, on wastelands, yards, meadows, hill slopes mainly exposed to sunshine but also in shady places. It has a fairly wide ecological distribution in terms of horizontal and vertical profiles. According to Forenbacher (1990), T. repens is distributed up to an altitude of $1400 \mathrm{~m}$ but, during our investigation, it was found up to the subalpine belt at $1885 \mathrm{~m}$ altitude.

Although a mesophytic plant, white clover succesfully copes with changes of ecological factors conditioned by increasing altitude and changing habitat. Phenotypic plasticity is highly important for plants, since they cannot move and must deal with changing environmental conditions. It also allows faster adjustment to a changing environment (Sultan 2000, Hoffman \& Sgro 2011). Phenotypic plasticity is the capacity of a single genotype to express different phenotypes in different environments, and it is assumed to be a mechanism for individual adaptation to environmental heterogeneity (Franel \& Steindor 2013).

Plants from high altitude locations experienced a reduction in size in most of the investigated micro- and macro-morphological traits, i.e., plant height, first and middle leaflet width and length, peduncle length, total calyx length, calyx tube length, short calyx teeth length, number of flowers in an inflorescence, stomata length on the upper leaf epidermis and diameter of the midrib vascular bundle. Our results are in conformity with the results of many authors (e.g., Kofidis \& Bosabalidis 2008, Yaqoob \& Ahmad 2015). The reduction in overall plant size is the most conspicuous structural alteration in plants observed along elevational gradients (Körner et al. 1989). Shortening of plant height in relation to an increase in altitude enables a plant to avoid the detrimental effects of strong winds that are present at high altitudes, and also improves conditions for photosynthetic activities, since the leaves of short plants are closer to the warm soil surface (Körner \& Chochrane 1983). In other authors' opinion (Atkin et al. 1996), a reduction of plant height at high altitude is related to slow plant growth due to unfavorable growth conditions. Mountain soils become less fertile and less developed as altitude increases. In cold mountain areas, freeze-and-thaw cycles reduce the aggregation of soils and, as a consequence, their stability, fertility and water retention (FAO 2015).

Since plants need to complete their growth cycle quickly when the time of growth conditions is very short, it is expected that the phenology, as well as leaf size, will differ from plants in lowlands (Kudo 1995, Michael et al. 1996, Cordell et al. 1999, Kao \& Chang 2001). This is attributed to the influence of low air temperature (Kao \& Chang 2001, Halil \& Rafet 2009).

Plant individuals from lowland locations with higher humidity, favorable land and air temperatures and higher soil fertility, showed better performance for all investigated micro- and macro-morphological traits. For example, plants from more productive habitats often have faster growth rates and larger structures, are taller relative to weight, and have thinner leaves and roots (Chapin 1980, Grime 1977).

The investigation carried out on a numerous microand macro-morphological traits indicated that almost all of them, with the only exception being trichomes, show significant variability between populations that inhabit different locations. In the majority of investigated traits, a significant difference was established between the population of location 2 (meadow with the highest humidity) and the remaining populations, and between populations from locations 12,11 , and 9 (hill slopes fully exposed to sunlight, low temperature, less favorable soil conditions) and other populations from locations with more favorable ecological conditions. It is understandable that their variability represents a response to habitat conditions and 
changes of temperature, light, moisture, precipitation, wind, geological composition of soil and other factors.

Trichome length on the lower leaf eidermis proved to be very consistent, despite changes in environmental conditions. Leaf epidermal tissue characteristics have an important role in taxonomy and the determination of the number of plant genera and species (Scatena et al. 2005). There is also no significant difference between populations in terms of trichome length in Trifolium pratense L. (Lluga et al 2014). It is therefore recommended as a credible micro-morphological trait for the taxonomic analysis of this taxon, since the leaf base shape is used in the taxonomy of Alnus sp. (Sabeti 1965). Indumentum characteristics, the composition, distribution and density of trichomes, as well as qualitative and quantitative characteristics of the stomata appear to be informative for the systematics of some genera (Selvi \& Bigazzi 2001). The interrelationships between climate and vegetation can be seen at a variety of spatial and temporal scales.

Leaves of Trifolium repens species are amphystomatic. It was found that the number of stomata in the upper leaf epidermis is regularly higher than in the lower leaf epidermis. Our results are in conformity with the results of other authors (Kofidis \& Bosabalidis 2008). Stomatal density can vary due to environmental factors, such as light, air humidity, water availability and atmospheric $\mathrm{CO}_{2}$ concentration (Woodward \& Kelly 1995). A postive correlation between stomata number in the upper leaf epidermis and increasing altitude was found, which is in accordance with the findings of Nicholas \& Andrew (2009). The results of stomata number in our study sites showed a significant difference between populations in shady places and populations that inhabit open places exposed to sunlight. Stomata are crucial in land plant productivity and survival. In general, with lower irradiance, stomatal and epidermal cell frequency per unit leaf area decreases, whereas guard-cell length or width increases (Pompelli et al 2010).

Bearing in mind that stomata length decreases with increasing altitude, but the number of stomata increases with increasing altitude, it is understandable that these two parameteres are in negative correlation, which is in conformity with the results of (Carpenter \& Smith 1975).

The results of palisade tissue length showed a significant difference between populations in shady and those in sunny locations. Typically, sun leaves of laminar-leaved plants are smaller and/or more deeply lobed, thicker, and lighter in color than shade leaves (Johnson et al 2005).

In conclusion, Trifolium repens is a highly variable plant species, which responds with high plasticity and visible phenological changes in trying to cope and adapt to new ecological environmental conditions and different habitats. High morphological variability enables white clover to compete sucessfully with plants in different habitats and to adapt to changes in ecological factors. High morphological variability enables this species to occupy and be distributed in a wide range of habitats.

\section{Acknowledgements}

We would like to thank the University of Prishtina for allocation of funds for this research.

Kimete Lluga-Rizani (D) https://orcid.org/0000-0003-2910-8245

Dubravka Šoljan (D) https://orcid.org/ 0000-0003-3863-7923

Naim Berisha (D) https://orcid.org/ 0000-0002-4715-0263

Kemajl Kurteshi (D) https://orcid.org/0000-0002-7443-4368

Kasum Letaj (D) https://orcid.org/0000-0003-3302-129X

\section{Supplementary material on-line}

\section{References}

Abberton, MT., Fothergil, M., Collins, RP. \& Marshall AH. 2006: Breeding forage legumes for sustainable and profitable farming systems. Aspects of Applied Biology 80: 81-87.

Archer, K. A \& Robinson, G. G. 1989: The role of stolons and seedlings in the persistence and production of white clover (Trifolium repens L.c.v. Huia ) in temperate pastures on the Northern Tablelands, New South Wales. Australian Journal of Agricultural Research 40: 605-616.

Atkin, O. K., Botman, B. \& Lambers, H. 1996: The Causes of Inherently Slow Growth in Alpine Plants: An analysis Based on the underlying Carbon Economies of Alpine and Lowland Poa Species. Functional Ecology 10: 698-707.

DOI: https://doi.org/10.2307/2390504

Carpenter, S. B. \& Smith, N. D. 1975: Stomatal Distribution and size in southern Appalachian hardwoods. Canadian Journal of Botany 53: 1153-1156. DOI: https://doi.org/10.1139/b75-137

Chapin, F. S. 1980: The mineral nutrition of wild plants. Annual Review of Ecology and Systematics 11: 233-260.

DOI: https://doi.org/10.1146/annurev.es.11.110180.001313

Cordell, S., Goldstein, G., Meinzer, F. C. \& Handley, L. L. 2002: Allocation of nitrogen and carbon in leaves of Metrosideros polymorpha regulates carboxylation capacity and $\delta 13 \mathrm{C}$ along an altitudinal gradient. Functional Ecology 13: 811-818.

DOI: https://doi.org/10.1046/j.1365-2435.1999.00381.x

Ellison, N. W., Liston, A., Steiner, J. J., Williams, W. M. \& Taylor, N. L. 2006: Molecular phylogenetics of the clover genus (Trifolium Legumiosae). Molecular Phylogenetics and Evolution 39: 688-705. DOI: https://doi.org/10.1016/j.ympev.2006.01.004

FAO 2015: Understanding Mountain Soils. Rome 169 pp. http:// www.fao.org/3/a-i4704e.pdf

Forenbacher, S. 1990: Velebit i njegov biljni svijet. Školska knjiga, Zagreb, $453 \mathrm{pp}$. 
Franel, I. \& Steindor, K. 2013. Preliminary studies on the morphological variability among Arabidopsis halleri populations from contrasting habitats. Annales Botanici Fennici 50: 142-148.

Grime, J. P. 1977: Evidence for the existence of three primary strategies in plants and its relevance to ecological and evolutionary theory. American Naturalist 111: 1169 -1194.

Halil, K. \& Rafet, A. 2009: The Effects of Altitude on Stomata Number and Some Vegetative Growth Parameters of Some Apple cultivars. Research Journal of Agriculture and Biological Sciences 5: 853-857.

Hoffman, A. A. \& Sgro, C. M. 2011: Climate change and evolutionary adaptation. Nature 470: 479-485. DOI: https://doi.org/10.1038/nature09670.

Jahufer, M. Z. Z., Cooper, M., Ayres, J. F. \& Bray, R. A. 2002 Identification of research to improve the efficiency of breeding strategies for white clover in Australia. Australian Journal of Agriculture Research 53: 239-257.

DOI: https://doi.org/10.1071/AR01110

Johnson, M., Smith, W. K.,Vogelmann, T. C. \& Brodersen, C. G. 2005: Leaf Architecture and Direction of Incident Light Influence Mesophyll Fluorescence Profiles. American Journal of Botany 92: 1425-1431. DOI: https://doi.org/10.3732/ajb.92.9.1425

Kao, W. Y. \& Chang, K. W. 2001: Altitudinal trends in photosynthetic rate and leaf characteristics of Miscanthus populations from central Taiwan. Australian Journal of Botany. 49: 509-14.

DOI: https://doi.org/10.1071/BT00028

Kofidis, G. \& Bosabalidis, A. M. 2008: Effects of altitude and season on glandular hairs and leaf structural traits of Nepeta nuda L. Greece Botanical Studies 49: 363-372.

Körner, C. \& Cochrane, P. 1983: Influence of plant physiognomy on leaf temperature on clear midsummer days in the Snowy Mountains, south-eastern Australia. Acta Oecologica 4:117-124.

Körner, C., Neumayer, M., Menendez-Riedl, S. P. \& Smeets-Scheel, A. 1989: Functional morphology of mountain plants. Flora 182 : 353-383.

Kudo, G. 1995: Altitudinal effects on leaf traits and shoot growth of Betula platyphylla var. japonica. Canadian Journal of Forest Research 25: 1881-1885. DOI: https://doi.org/10.1139/x95-203

Lewis, G. P. 2005: Caesalpinieae. In: Lewis, G., Schrire, B., Mackinder, B., Lock, M. (eds.): Legumes of the world, Richmond, UK, Royal Botanic Gardens, Kew, pp. 127-161.

Lluga, K., Šoljan, D. \& Sherifi, E. 2014: Samples of Ecological Morphological differentiation of Trifolium pratense L. in Vertical Profile of Brezovica (Sharri Mountain, Kosovo). Ecology and Safety 8: $135-145$.

Michael, D., Morecroft, F. \& Woodward, F. 1996: Experiments on the Causes of Altitudinal Differences in the Leaf Nutrient Contents, Size and $813 \mathrm{C}$ of Alchemilla alpina. New Phytology 134: 471-479. DOI: https://doi.org/10.1111/j.1469-8137.1996.tb04364.x
Nicholas, H. \& Andrew, D. R. 2009: Stomatal length Correlates with Elevation of Growth in Four Temperate Species. Journal of Sustainable Forestry 28: 63-73.

DOI: https://doi.org/10.1080/10549810802626142

Pllana, R. 2015: Climate of Kosovo. Kosovo Academy of Sciences and Arts, Prishtina, 320 pp.

Pompelli. M. F., Martins, S. C. V., Celin, E. F., Ventrella , M. C. \& DaMatta, F. M. 2010: What is the influence of ordinary epidermal cells and stomata on the leaf plasticity of coffee plants grown under full-sun and shady conditions? Brazilian Journal of Biology 70: 10831088. DOI: https://doi.org/10.1590/s1519-69842010000500025

Sabeti, H. 1965: Trees and shrubs native to Iran. Tehran University Press. 430 pp.

Snaydon, R. W. 1962: Micro-distribution of Trifolium repens L. and its relation to soil factors. Journal of Ecology 50: 133-143. DOI: https://doi.org/10.2307/2257198

Scatena, V. L., Giulietti, A. M., Borba, E. L. \& van der Berg, C., 2005: Anatomy of Brasilian Eriocaulaceae: correlation with taxonomy and habitat using multivariate analyses. Plant Systematic Evolution 253: 1-22. DOI: https://doi.org/10.1007/s00606-004-0295-z

Selvi, F. \& Bigazzi, M. 2001: Leaf surface and anatomy in Boraginaceae tribe Boragineaea with respect to ecology and taxonomy. Flora 196: 269-285. DOI: https://doi.org/ https://doi.org/10.1016/s03672530(17)30056-7

Sultan, S. E. 2000: Phenotypic plasticity for plant development, function and leaf history. Trends in Plant Science 5: 537-542. DOI: https://doi.org/10.1016/s1360-1385(00)01797-0

Turkington, R. \& Burdon, J. J. 1983: Biology of Canadian weeds, 57. Trifolium repens L. Canadian Journal of Plant Science 63: 243-266.

Williams, W. M. 1987: White clover taxonomy and biosystematics. In: Baker, M. J. \& Williams W. M. (eds.): White clover, Waillingford, CAB International, pp. 323-342.

Woodward, F. I \& Kelly, C. K. 1995. The influence of $\mathrm{Co}^{2}$ concentration on stomatal density. New Phytologist 131: 311-327. DOI: https://doi.org/10.1111/j.1469-8137.1995.tb03067.x

Yaqoob, U. \& Ahmad, N. I. 2015: Impact of habitat variability and altitude on growth dynamics and reproductive allocation in Ferula jaeschkeana Vatke. Journal of King Saud University- Science 29: 19-27. DOI: https://doi.org/10.1016/j.jksus.2015.10.002

Zhenzhu, X. \& Guangsheng, Zh. 2008: Responses of leaf stomatal density to water status and its relationship with photosynthesis in a grass. Journal of Experimental Botany 59: 3317-3325.

DOI: https://doi.org/10.1093/jxb/ern185 